yielded by the observations I have made, when grouped together roughly according to altitude. The results are :-

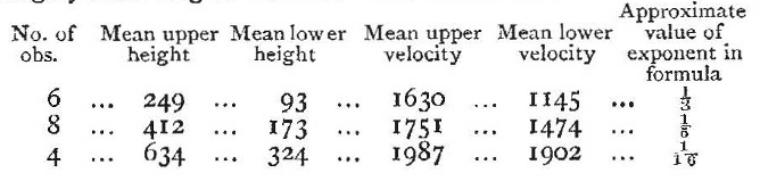

Thus, while the velocity invariably increases as we ascend, the rate rapidly diminishes after the first 200 or 300 feet. It must, however, be remembered that the place of observation is itself 500 feet above sea-level, and though this would probably not affect the results near the surface, the air above 200 feet must be moving with very nearly the same velocity as it would have at its real elevation above a sea-level surface. Adding therefore the 500 feet to both heights in the case of the two last groups, we get, for the value of $x, \frac{1}{3}$ and $\frac{1}{4}$ instead of $\frac{1}{5}$ and $\frac{1}{15}$. These two values are probably nearer the truth than those in the table, and hover round the mean value $\frac{1}{4}$, which I have already stated was found to hold for Vettin's cloud velocities up to 25,000 feet. In any case it is plain that Mr. Stevenson's formula cannot be taken to hold beyond his 50 -foot pole.

Further observations will, I trust, give a trustworthy basis for determining the variations in the velocity-increment corresponding to the direction and absolute velocity of the wind as well as those corresponding to season, humidity, temperature, and pressure. To thoroughly investigate the velocity-increment under all such conditions, and thus to afford data to the physicist who desires to construct the hitherto unwritten science of aerodynamics, will be one of the objects of my experiments during the coming year.

P.S. October 22.-Since the foregoing observations were made I have succeeded in getting readings with the anemometers at heights of over I Ioo feet above the ground, or I 600 feet above sea-level.

\section{THE CLASSIFICATION AND AFFINITIES OF DINOSAURIAN REPTILES ${ }^{1}$}

I $N$ this paper the author presented briefly the results of a study of Dinosaurian reptiles on which he had been engaged for several years. The complete results will be published in a series of monographs now in preparation. The material on which the investigation is mainly based consists of the remains of several hundred individuals of this group collected in the Rocky Mountains by the author, and now preserved in the museum of Yale College. Other important American specimens have been examined by the author, who has also studied with care the more important specimens of this group in the museums of Europe. The investigation is not yet completed, but the results already attained seem to be of sufficient interest to present to the $\Lambda$ ssociation at this time.

In previous publications on this subject the author had expressed the opinion that the Dinesauria should be regarded, not as an order, but as a sub-class, and his later researches confirm this view. The great number of subordinate divisions in the group, and the remarkable diversity among those already discovered, indicate that many new forms will yet be found. Among those already known there is a much greater difference in size and structure than in any other sub-class of vertebrates, with the exception of the placental mammals. Compared with the Marsupials, living and extinct, the Dinssauria show an equal diversity of structure and size.

According to present evidence, the Dinosaurs were confined entirely to the Mesozoic Age. They were abundant in the Jurassic, and continued in diminishing numbers to the end of the Cretaceous period, when they became extinct. The great variety of forms that flourished in the Triassic renders it more than probable that some members of the group existed in the Permian period, and their remains may be brought to light at any time. The Triassic Dinosaurs, although very numerous, are known to-day mainly from footprints and fragmentary osscous remains; hence, many of the forms described cannot at present be referred to their appropriate divisions in the group. Fron the Jurassic, however, during which period Dinosaurian reptiles reached their zenith in size and numbers, representatives of no less than four well-marked orders are now so well known that I. Paper read at the Montreal Meeting of the British $A$ ssociation, by Prof.
c. Marsh. different families and genera can be very accurately determined, and almost the entire osseous structure of typical examples, at least, can be made out with certainty. Comparatively little is yet known of Cretaceous Dinosaurs, although many have been described from incomplete specimens. All these appear to have been of large size, but much inferior in this respect to the gigantic forms of the previous period. The remains best preserved show that, before extinction, some members of the group became quite highly specialised.

Regarding the Dinosaurs as a sub-class of the Reptilia, the ferms best known at present may be classified as follows :-

SUB-Ci.ASS DINOSAURIA.-Premaxillary bones separate ; upper and lower temporal arches; rami of lower jaw united in front by cartilage only; no teeth on palate. Neural arches of vertebræ united to centra by suture; sacral vertebræ co-ossified. Cervical and thoracic ribs double-headed. Ilium prolonged in front of acetabulum; acetabulumiformed in part by pubis ; ischia meet distally on median line. Fore and hind limbs present, the latter ambulatory and larger than those in front; head of femur at right angles to condyles; tibia with procnemial crest ; fibula complete. First row of tarsals composed of astragalus and calcaneum only, which together form the upper portion of ankle joint.

(I.) Order SAUROPODA (LIZARD-FoOT).-Herbivorous. Premaxillary bones with teeth. Large antorbital opening. Anterior nares at apex of skull. Post-occipital bones. Anterior vertebra opisthoccelian ; cervical ribs co-ossified with vertebræ; pre-sacral vertebræ hollow; each sacral vertebra supports its own transverse process. Fore and hind limbs nearly equal; limb bones solid. Feet plantigrade, ungulate; five digits in manus and pes; second row of carpal and tarsal bones unossified. Sternal bones parial. Pubes projecting in front, and united distally by cartilage ; no post-pubis.

(I) Family Atlantosaurida.-A pituitary canal. Ischia directed downward, with expanded extremities meeting on median line. Sacrum hollow. Anterior caudals with lateral cavities. Genera : Atlantosaurus, Apatosaurus, Brontosaurus.

(2) Family Diplodocide.-Dentition weak. Brain inclined backward. Large pituitary fossa. Two antorbital openings. Ischia with straight shaft, not expanded distally, directed downward and backward, with ends meeting on median line. Caudals deeply excavated below. Chevrons with both anterior and posterior branches. Genus : Diplodocus.

(3) Family Morosaurida.-Small pituitary fossa. Ischia slender, with twisted shaft, directed backward, and sides meeting on median line. Anterior caudals solid. Sacral vertebræ solid. Genus : Morosaurus. European forms of this order: Bothriospondylus, Ceteosaurus, Eucamerotus, Ornithopsis, Pelorosaurus.

(II.) Order Stegosauria (Plated Lizard).-Herbivorous. Feet plantigrade, ungulate ; five digits in manus and pes; second row of carpals unossified. Pubes projecting free in front ; postpubis present. Fore limbs small; locomotion mainly on hind limbs. Cervical ribs free. Vertebræ and limb bones solid. Osseous dermal armour.

(r) Family Slegosaurida.-Vertebræ bi-concave. Neural canal in sacrum expanded into large chamber; ischia directed backward, with sides meeting on median line. Astragalus co-ossified with tibia; metapodials very short. Genera: Stegosaurus (Hypsirhophus), Diracodon; and in Europe, Omosaurus (Owen).

2. Family Scelidosauridce.-Astragalus not co-ossified with tibia; metatarsals elongated; four functional digits in pes. Known forms all European. Genera : Scelidosaurus, Acanthopholis, Cratæomus, Hylæosaurus, Polacanthus.

(III.) Order ORNITHOPODA (BIRD-FOOT).- Herbivorous, Feet digitigrade, five functional digits in manus and three in pes. Pubes projecting free in front; post-pubis present. Vertebræ solid. Cervical ribs free. Fore limbs small; limb bones hollow. Premaxillaries edentulous in front. A premandibular bone.

(I) Family Camptonotida. -Clavicles wanting ; post-pubis complete. Genera : Camptonotus, Laosaurus, Nanosaurus; and in Europe, Hypsilophodon.

(2) Family Igumnodontide--Post-pubis incomplete. Premaxillaries edentulous. Known forms all European. Genera : Iguanodon, Vectisaurus. 
yielded by the observations I have made, when grouped together roughly according to altitude. The results are :-

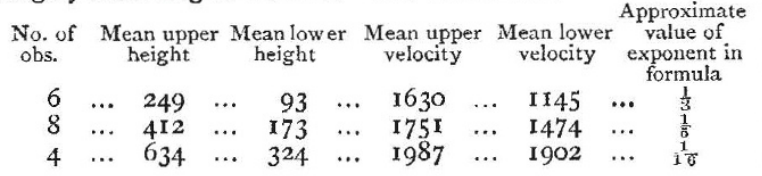

Thus, while the velocity invariably increases as we ascend, the rate rapidly diminishes after the first 200 or 300 feet. It must, however, be remembered that the place of observation is itself 500 feet above sea-level, and though this would probably not affect the results near the surface, the air above 200 feet must be moving with very nearly the same velocity as it would have at its real elevation above a sea-level surface. Adding therefore the 500 feet to both heights in the case of the two last groups, we get, for the value of $x, \frac{1}{3}$ and $\frac{1}{4}$ instead of $\frac{1}{5}$ and $\frac{1}{15}$. These two values are probably nearer the truth than those in the table, and hover round the mean value $\frac{1}{4}$, which I have already stated was found to hold for Vettin's cloud velocities up to 25,000 feet. In any case it is plain that Mr. Stevenson's formula cannot be taken to hold beyond his 50 -foot pole.

Further observations will, I trust, give a trustworthy basis for determining the variations in the velocity-increment corresponding to the direction and absolute velocity of the wind as well as those corresponding to season, humidity, temperature, and pressure. To thoroughly investigate the velocity-increment under all such conditions, and thus to afford data to the physicist who desires to construct the hitherto unwritten science of aerodynamics, will be one of the objects of my experiments during the coming year.

P.S. October 22.-Since the foregoing observations were made I have succeeded in getting readings with the anemometers at heights of over I Ioo feet above the ground, or I 600 feet above sea-level.

\section{THE CLASSIFICATION AND AFFINITIES OF DINOSAURIAN REPTILES ${ }^{1}$}

I $N$ this paper the author presented briefly the results of a study of Dinosaurian reptiles on which he had been engaged for several years. The complete results will be published in a series of monographs now in preparation. The material on which the investigation is mainly based consists of the remains of several hundred individuals of this group collected in the Rocky Mountains by the author, and now preserved in the museum of Yale College. Other important American specimens have been examined by the author, who has also studied with care the more important specimens of this group in the museums of Europe. The investigation is not yet completed, but the results already attained seem to be of sufficient interest to present to the $\Lambda$ ssociation at this time.

In previous publications on this subject the author had expressed the opinion that the Dinesauria should be regarded, not as an order, but as a sub-class, and his later researches confirm this view. The great number of subordinate divisions in the group, and the remarkable diversity among those already discovered, indicate that many new forms will yet be found. Among those already known there is a much greater difference in size and structure than in any other sub-class of vertebrates, with the exception of the placental mammals. Compared with the Marsupials, living and extinct, the Dinssauria show an equal diversity of structure and size.

According to present evidence, the Dinosaurs were confined entirely to the Mesozoic Age. They were abundant in the Jurassic, and continued in diminishing numbers to the end of the Cretaceous period, when they became extinct. The great variety of forms that flourished in the Triassic renders it more than probable that some members of the group existed in the Permian period, and their remains may be brought to light at any time. The Triassic Dinosaurs, although very numerous, are known to-day mainly from footprints and fragmentary osscous remains; hence, many of the forms described cannot at present be referred to their appropriate divisions in the group. Fron the Jurassic, however, during which period Dinosaurian reptiles reached their zenith in size and numbers, representatives of no less than four well-marked orders are now so well known that I. Paper read at the Montreal Meeting of the British $A$ ssociation, by Prof.
c. Marsh. different families and genera can be very accurately determined, and almost the entire osseous structure of typical examples, at least, can be made out with certainty. Comparatively little is yet known of Cretaceous Dinosaurs, although many have been described from incomplete specimens. All these appear to have been of large size, but much inferior in this respect to the gigantic forms of the previous period. The remains best preserved show that, before extinction, some members of the group became quite highly specialised.

Regarding the Dinosaurs as a sub-class of the Reptilia, the ferms best known at present may be classified as follows :-

SUB-Ci.ASS DINOSAURIA.-Premaxillary bones separate ; upper and lower temporal arches; rami of lower jaw united in front by cartilage only; no teeth on palate. Neural arches of vertebræ united to centra by suture; sacral vertebræ co-ossified. Cervical and thoracic ribs double-headed. Ilium prolonged in front of acetabulum; acetabulumiformed in part by pubis ; ischia meet distally on median line. Fore and hind limbs present, the latter ambulatory and larger than those in front; head of femur at right angles to condyles; tibia with procnemial crest ; fibula complete. First row of tarsals composed of astragalus and calcaneum only, which together form the upper portion of ankle joint.

(I.) Order SAUROPODA (LIZARD-FoOT).-Herbivorous. Premaxillary bones with teeth. Large antorbital opening. Anterior nares at apex of skull. Post-occipital bones. Anterior vertebra opisthoccelian ; cervical ribs co-ossified with vertebræ; pre-sacral vertebræ hollow; each sacral vertebra supports its own transverse process. Fore and hind limbs nearly equal; limb bones solid. Feet plantigrade, ungulate; five digits in manus and pes; second row of carpal and tarsal bones unossified. Sternal bones parial. Pubes projecting in front, and united distally by cartilage ; no post-pubis.

(I) Family Atlantosaurida.-A pituitary canal. Ischia directed downward, with expanded extremities meeting on median line. Sacrum hollow. Anterior caudals with lateral cavities. Genera : Atlantosaurus, Apatosaurus, Brontosaurus.

(2) Family Diplodocide.-Dentition weak. Brain inclined backward. Large pituitary fossa. Two antorbital openings. Ischia with straight shaft, not expanded distally, directed downward and backward, with ends meeting on median line. Caudals deeply excavated below. Chevrons with both anterior and posterior branches. Genus : Diplodocus.

(3) Family Morosaurida.-Small pituitary fossa. Ischia slender, with twisted shaft, directed backward, and sides meeting on median line. Anterior caudals solid. Sacral vertebræ solid. Genus : Morosaurus. European forms of this order: Bothriospondylus, Ceteosaurus, Eucamerotus, Ornithopsis, Pelorosaurus.

(II.) Order Stegosauria (Plated Lizard).-Herbivorous. Feet plantigrade, ungulate ; five digits in manus and pes; second row of carpals unossified. Pubes projecting free in front ; postpubis present. Fore limbs small; locomotion mainly on hind limbs. Cervical ribs free. Vertebræ and limb bones solid. Osseous dermal armour.

(r) Family Slegosaurida.-Vertebræ bi-concave. Neural canal in sacrum expanded into large chamber; ischia directed backward, with sides meeting on median line. Astragalus co-ossified with tibia; metapodials very short. Genera: Stegosaurus (Hypsirhophus), Diracodon; and in Europe, Omosaurus (Owen).

2. Family Scelidosauridce.-Astragalus not co-ossified with tibia; metatarsals elongated; four functional digits in pes. Known forms all European. Genera : Scelidosaurus, Acanthopholis, Cratæomus, Hylæosaurus, Polacanthus.

(III.) Order ORNITHOPODA (BIRD-FOOT).- Herbivorous, Feet digitigrade, five functional digits in manus and three in pes. Pubes projecting free in front; post-pubis present. Vertebræ solid. Cervical ribs free. Fore limbs small; limb bones hollow. Premaxillaries edentulous in front. A premandibular bone.

(I) Family Camptonotida. -Clavicles wanting ; post-pubis complete. Genera : Camptonotus, Laosaurus, Nanosaurus; and in Europe, Hypsilophodon.

(2) Family Igumnodontide--Post-pubis incomplete. Premaxillaries edentulous. Known forms all European. Genera : Iguanodon, Vectisaurus. 
(3) Family Hadrosaurida. - Teeth in several rows, forming with use a tesselated grinding surface. Anterior vertebrx opisthocoelian. Genera: Hadrosaurus (Diconius ?), Agathaumas, Cionodon.

(IV.) Order Theropoda (BEAst-Foot).-Carnivorous. Premaxillary bones with teeth. Anterior nares at end of skull. Large antorbital opening. Vertebræ more or less hollow. Feet digitigrade; digits with prehensile claws. Pubes projecting downward, with distal ends co-ossified.

(I) Family Megalosaurida.-Anterior vertebræ convexo-concave ; remaining vertebrac bi-concave. Pubes slender. Astragalus with ascending process. Genera: Megalosaurus (Poikilopleuron), Allosaurus, Cœlosaurus, Creoszurus, Drvptosaurus (Lælops).

(2) Family Labrosaurida.-Lower jaws edentulous in front. Cervical and dorsal vertebræ convexo-concave. Pubes slender, with anterior margins united. Astragalus with ascending process. Genus : Labrosaurus.

(3) Family Zanclodontida. - Vertebra bi-concave. Pubes broad elongate plates, with anterior margins united. Astragalus without ascending process. Five digits in manus and pes. Genera : Zanclodon (?), Teratosaurus.

(4) Family Amphisaurida.-Vertebræ bi-concave. Pubes rod-like. Five digits in manus, and three in pes. Genera : Amphisaurus (Megadactylus ?), Bathygnathus (?), Clepsysaurus, Palæosaurus, Thecodontosaurus.

(a) Sub-order Cailuria.-(5) Family Coturida.-Vertebra and bones of skeleton pneumatic. Anterior cervicals convexoconcave; remaining vertebræ bi-concave. Cervical ribs coossified with vertebræ. Metatarsals very long and slender. Genus : Cœlurus.

(b) Sub-order Compsognatira.-(6) Family Compsognathida.-Cervical vertebræ convexo-concave; remaining vertebræ bi-concave. Three functional digits in manus and pes. Ischia with long symphisis on median line. Genus : Compsognathus.

(c) Sub-order Cerastosauria.-(7) Family Ceratosaurida. - Horn on skull. Cervical vertebræ plano-concave; remaining vertebræ bi-concave. Pubes slender. Pelvic bones co-ossified. Osseous dermal plates. Astragalus with ascending process. Metatarsals co-ossified. Genus : Ceratosaurus.

The four orders defined above, which the author first established for the reception of the American Jurassic Dinosaurs, appear to be all natural groups, well marked in general from each other. The European Dinosaurs from deposits of corresponding age fall readily into the same divisions, and, in some cases, admirably supplement the series indicated by the American forms. The more important remains from other formations in this country and in Europe, so far as their characters have been made out, may likewise be referred with certainty to the same orders.

The three orders of herbivorous Dinosaurs, although widely different in their typical forms, show indications of approximation in some of their aberrant genera. The Sauropoda for example, with Atlantosaurus and Brontosaurus, of gigantic size, for their most characteristic members, have in Morosaurus a branch leading towards the Stegosauria. The latter order, likewise, although its type genus represents in many respects the most strongly marked division of the Dinosaurs, has in Scelido. saurus a form with some features pointing strongly toward the Ornithopoda.

The carnivorous Dinosauria now best known may all be placed at present in a single order, and this is widely separated from those that include the herbivorous forms. The three suborders here defined include very aberrant forms, which show many points of resemblance to Mesozoic birds. Among the more fragmentary remains belonging to this order, this resemblance appears to be carried much farther.

The Amphis zurida and the Zanclodontida, the most generalised families of the Dinosauria, are known only from the Trias. The typical gencra, however, of all the orders and sub-orders, are Jurassic forms, and on these especially the present classification is based. The Hadrosauride are the only family confined to the Cretaceous. Above this formation there appears to be at present no satisfactory evidence of any Dinosauria.

The peculiar orders Hallopoda and Aëtosauria include carnivorous reptiles which are allied to the Dinosauria, but they differ from that group in some of its most characteristic features. In both Aëlosaurus and Hallopus the calcaneum is much produced backwards. In the former genus the entire limbs are crocodilian, and this is also true of the dermal covering. In both of these genera there are but two sacral vertebræ, but this may be the case in true Dinosaurs, especially from the Trias. Future discoveries will probably bring to light intermediate forms between these orders and the typical Dinosaurs. The Crocodilia have some some strong affinities with the Dinosauria, especially with those of the order Sazropoda. The extinct genus Belodon of the Triassic, for example, resembles Diplodocus, particularly in the large antorbital vacuities of the skull, the posterior position of the external nasal aperture, as well as in other features. The Rhynchocephala, represented by the genus Hatteria, have several important characters in common with the Dirosauria, and, as the former is evidently an ancient type, it is probable that a real affinity may exist between these two groups.

That birds are closely related to Dinosaurs there is no longer any question. In addition to the various characters which these groups have been known to share with each other, two more may be added in consequence of discoveries made during the past year. The genus Ceratosaurus, a carnivorous Dinosaur from the Jurassic of the Rocky Mountains, recently described by the author, has the pelvic bones co-ossified, as in all known birds, living and extinct, except Archreopteryx. The same reptile, moreover, has the metatarsal bones firmly united, as in all adult birds, with possibly the single exception of Archaopteryx, while all the known Dinosauria, except Ceratosaurus, have both the pelvic and the metatarsal bones separate. The exception in each case brings birds and reptiles near together at this point, and their close affinity is now a matter of demonstration.

\section{THE DANISH EXPEDITION IN GREENLAND}

$W^{E}$ have on previous occasions referred to the Expedition under Lieuts. Holm and Garde, which has for more than a year been engaged in exploring the east coast of Greenland, and we are now able to supplement this with an interesting report from Lieut. Holm, written in the spring, from the winter quarters of the Expedition, and received some time ago by sailing-vessel at Copenhagen.

The place where the Expedition wintered is called Namortalik, and lies on the east coast, about fifty miles, as the crow flies, from Cape Farewell. It is also called Björneorten (the "bear-haunt"), from the many bears in the neighbourhood. After an excursion lasting two months and a half during the summer of 1883, the Expedition returned in September to Namortalik, but the huts for wintering not being finished, they started for a week's further excursion to the Fredriksdalsfjord, between Namortalik and Cape Farewell.

It was not until the end of October that the Expedition could begin their regular scientific observations at the station, but after that date they were continued without interruption through the winter. As, however, the chief object of the Expedition was to explore the east coast in boats, the scientific observations have not been so rich as those, for instance, of the Danish International Expedition at Godthaab in 1882-83 (NATURE, vol. xxix. p. "337); but every effort was made to adhere as strictly as possible to the programme of the International Polar Commission. The meteorological observations were made every third hour from 8 p.m. to 8 a.m., and the magnetic observations every hour except at 3 and $4 \mathrm{a}, \mathrm{m}$. On the Ist and 5th of every month the magnetic instruments were read every fifth minute during eight hours and every twentieth second during one hour.

With reference to the climatological conditions of the east coast, we learn that the winter is very raw and severe, although it cannot be said to be of excessive duration. The pleasant, calm, frosty weather which is experienced in North Greenland seldom prevails on the east coast, but in its stead there are fre. quent and sudden changes and violent storms; there being, for instance, one day $20^{\circ} \mathrm{C}$. of frost, and the next several degrees of heat, while heavy rains and snows alternate. In consequence of these sudden changes it is impossible in East Greenland to employ the mode of locomotion so valuable in other parts, viz. the dog-sledge. The only means of conveyance here is by boat. If, therefore, the sea is frozen over for a time, the inhabitants remain where they are, and wait patiently until a higher temperature removes the obstacle. The ice never becomes firm enough to bear a man and sledge.

Up to January last the temperature had not fallen lower than $15^{\circ} .5$ C. - about Christmas-the glass generally standing between 